\title{
FIRST RECORD OF THE TOOTHY GOBY, PLEUROSICYA MOSSAMBICA, FROM ISRAEL, GULF OF AQABA, RED SEA, AND STATUS OF P. SINAIA (ACTINOPTERYGII: PERCIFORMES: GOBIIDAE)
}

\author{
Ronald FRICKE ${ }^{1,2 *}$, Daniel GOLANI ${ }^{3}$, and Brenda APPELBAUM-GOLANI ${ }^{4}$ \\ ${ }^{1}$ Im Ramstal 76, 97922 Lauda-Königshofen, Germany \\ ${ }^{2}$ Staatliches Museum für Naturkunde, Rosenstein 1, 70191 Stuttgart, Germany [temporarily out of office] \\ ${ }^{3}$ National Natural History Collections and Department of Ecology, Evolution and Behavior, The Hebrew University \\ of Jerusalem, 91904 Jerusalem, Israel \\ ${ }^{4}$ Mt. Scopus Library, The Hebrew University of Jerusalem, 91905 Jerusalem, Israel
}

Fricke R., Golani D., Appelbaum-Golani B. 2015. First record of the toothy goby, Pleurosicya mossambi$c a$, from Israel, Gulf of Aqaba, Red Sea, and status of P. sinaia (Actinopterygii: Perciformes: Gobiidae). Acta Ichthyol. Piscat. 45 (2): 217-219.

\begin{abstract}
The toothy goby, Pleurosicya mossambica Smith, 1959, is recorded for the first time from Eilat, Israel, Gulf of Aqaba. The status of Pleurosicya sinaia Goren, 1984 is discussed; that nominal species is treated as a junior synonym of $P$. mossambica.
\end{abstract}

Keywords: Pleurosicya mossambica, Gobiidae, Red Sea, Israel, first record, distribution

Pleurosicya sinaia Goren, 1984 was recorded from the Sinai coast of Egypt from two locations along the coast of Sinai, Egypt, based on two specimens in the TAU collection. The holotype originated from Marsa Barecha on the southeastern coast of Sinai; one paratype was collected in the northern Gulf of Aqaba ca. $7 \mathrm{~km}$ south of Taba. Pleurosicya sinaia was tentatively synonymised with Pleurosicya mossambica Smith, 1959 by Larson (1990: 32), but Eschmeyer (2014) treated it as a valid species based on Goren and Dor (1994: 66). Goren (1984) also reported two specimens of $P$. mossambica from Marsa Barecha, southern Sinai. The discovery of additional specimens provided the opportunity to clarify the status of Pleurosicya sinaia, and to report P. mossambica from Israel for the first time.

Specimens of Pleurosicya mossambica from Eilat, Israel were recently discovered in the fish collection of the Hebrew University of Jerusalem. Counts and measurements followed Hubbs and Lagler (1947); the classification follows Eschmeyer (2014).

\section{Comparative material}

- Pleurosicya bilobata (Koumans, 1941): SMNS 21549 (3), New Caledonia, Grande Terre;
- Pleurosicya micheli Fourmanoir, 1971: SMNS 2111 (2), Réunion; SMNS 21170 (2), Réunion; SMNS 21171 (2), Réunion; SMNS 23834 (1), Loyalty Islands, Lifou; - P. mossambica: AMS I.29793-001 (7), Australia, New South Wales; NTM S.12228-003 (3), Papua New Guinea, Port Moresby; SMNS 21261 (1), Egypt, Al-Qusayr, Red Sea; SMNS 21511 (4), Yemen, Red Sea.

GOBIIDAE

Pleurosicya mossambica Smith, 1959

Material examined. HUJ 6682, 7 specimens, 17.8-25.5 mm SL, Israel, Eilat, Gulf of Aqaba, Red Sea, Hans Fricke, 15 Apr 1969.

Description. (Figs. 1-3) Counts see Table 1. Body robust, elongate, depressed. Head and anterior half of body triangular. Snout profile wide, rectangular in most specimens (narrow in 1 specimen). Tongue blunt. Gill opening wide, reaching to below level of posterior half of eye. Pelvic fins round, cup-like, nearly reaching anus when straightened; rays not broad and flattened before first branch point, but rather flattened between first and second branch points (Fig. 3). Pelvic spine lobes triangular, each lobe usually somewhat divided and folded; lobes and frenum usually 
fimbriate. Nape fully scaled to behind eyes, in some specimens midline of nape naked but sides scaled.

Color of preserved specimen (Figs. 1-3): head and body pale. Eyes grey with black pupil. First dorsal fin with basal dark blotch.
Discussion. Pleurosicya sinaia was described by Goren (1984: 74), based on two specimen from the Gulf of Aqaba coast of Egypt. At the type locality, Marsa Barecha on the south coast of Sinai, he found the species to co-occur with Pleurosicya mossambica. Goren examined

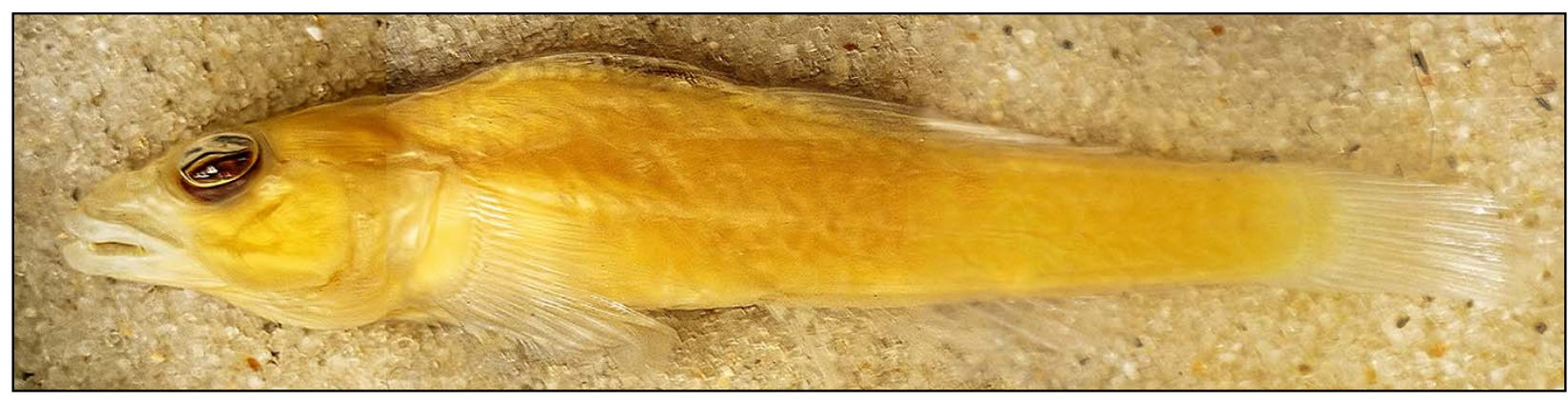

Fig. 1. Pleurosicya mossambica, HUJ 6682, specimen 1, 25.5 mm (SL), Israel, Eilat, H. Fricke, 15 Apr 1969. Lateral view; Photograph by E. G. Regev and D. Darom

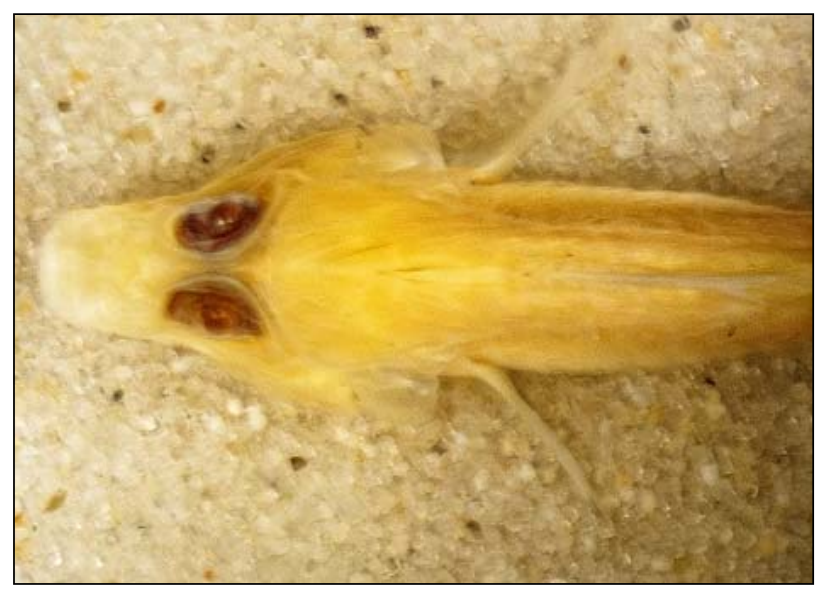

Fig. 2. Pleurosicya mossambica, HUJ 6682, specimen 2, $23.2 \mathrm{~mm}$ (SL), Israel, Eilat, H. Fricke, 15 Apr 1969; Head, dorsal view; Photograph by E. G. Regev and D. Darom

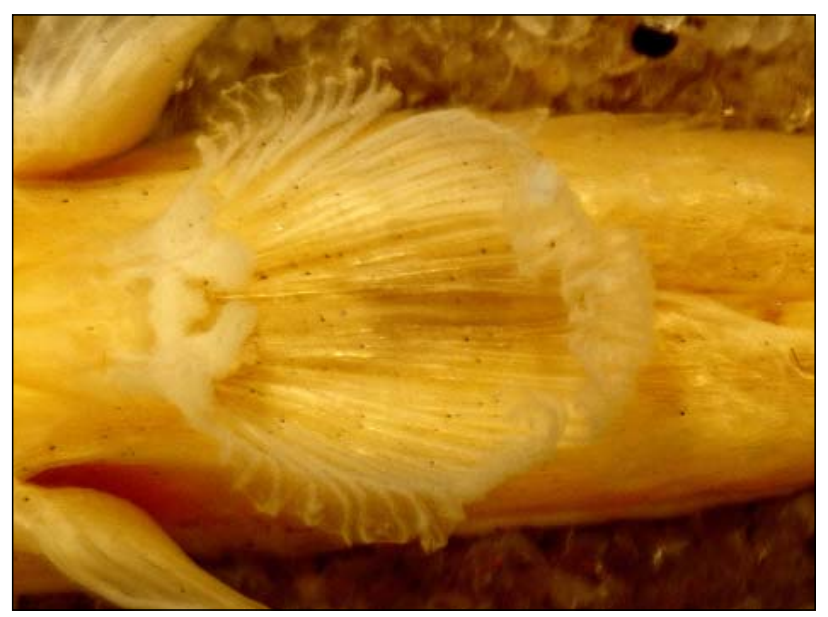

Fig. 3. Pleurosicya mossambica, HUJ 6682, specimen 2, $23.2 \mathrm{~mm}$ (SL), Israel, Eilat, H. Fricke, 15 Apr 1969; Pelvic fins; Photograph by E. G. Regev and D. Darom
2 specimens of $P$. mossambica and 1 specimen of $P$. sinaia from that locality. Pleurosicya sinaia was characterised by having 26-27 lateral-line scales (versus 28 in P. mossambica), 6 soft rays in the second dorsal fin (versus 8 ); the snout of the illustrated holotype was relatively blunt when seen from above.

Larson (1990: 36) re-examined the holotype and paratype of $P$. sinaia, and found that they actually had 8 soft rays in the second dorsal fin, not 6 . She concluded that the specimens of $P$. sinaia were well in the range of $P$. mossambica, though a little more compressed, and synonymised the species with P. mossambica. Yet, Goren and Dor (1994: 66) treated $P$. sinaia as valid; they were followed by Eschmeyer (2014). Golani and Bogorodsky (2010: 82), however, followed Larson (1990) in synonymising the species with $P$. mossambica.

The discovery of 7 additional specimens from the Gulf of Aqaba in the HUJ collection (HUJ 6682) provided the opportunity to reconsider the taxonomic identity of Pleurosicya sinaia. The fin-ray and scale counts of the specimens were found to fully agree with the range of P. mossambica; the body shape was also depressed, similar to $P$. mossambica from other regions. The pelvic fin shape (see Fig. 3, as described above) were within the variation of $P$. mossambica as well; the description by Goren (1984: 76) as not reaching the anus was somewhat misleading, as the fin rays are nearly reaching the anus when straightened. This was also shown in the drawing by Goren (1984: 75, Fig. 2). Only the snout shape when seen from above was usually broad and rectangular (Fig. 2 ), and only in one specimen narrower. In specimens of P. mossambica from other regions, we observed more variation in this character. However, we consider the snout shape as not sufficient to distinguish the Gulf of Aqaba populations as a separate species, and therefore agree with Larson (1990) in treating Pleurosicya sinaia as a junior synonym of $P$. mossambica. 
Table 1

Counts and snout shape of specimens of Pleurosicya mossambica, HUJ 6682, 17.8-25.5 mm (SL), Israel, Eilat, H. Fricke, 15 Apr. 1969

\begin{tabular}{llllllll}
\hline \multicolumn{1}{c}{ Specimen } & \multicolumn{1}{c}{1} & \multicolumn{1}{c}{2} & \multicolumn{1}{c}{3} & \multicolumn{1}{c}{4} & \multicolumn{1}{c}{6} & \multicolumn{1}{c}{ ( } \\
\hline SL $[\mathrm{mm}]$ & 25.5 & 23.2 & 20.8 & 20.3 & 18.7 & 18.3 & 17.8 \\
Dorsal-fin spines & $\mathrm{VI}+\mathrm{I}$ & $\mathrm{VI}+\mathrm{I}$ & $\mathrm{VI}+\mathrm{I}$ & $\mathrm{VI}+\mathrm{I}$ & $\mathrm{VI}+\mathrm{I}$ & $\mathrm{VI}+\mathrm{I}$ & VI + I \\
Dorsal-fin rays & 8 & 8 & 8 & 8 & 8 & 8 & 8 \\
Anal-fin rays & $\mathrm{I}, 8$ & $\mathrm{I}, 8$ & $\mathrm{I}, 8$ & $\mathrm{I}, 8$ & $\mathrm{I}, 8$ & $\mathrm{I}, 8$ & $\mathrm{I}, 8$ \\
Pectoral-fin rays & 19 & 18 & 17 & 16 & 18 & 19 & 17 \\
Lateral-line scales & 26 & 25 & 24 & 27 & 24 & ca. 25 & 20 \\
Snout shape & Wide & Wide & Wide & Moderate & Wide & Wide & Wide \\
\hline
\end{tabular}

\section{ACKNOWLEDGEMENTS}

We would like to thank Dr. Efrat Gavish Regev and Dr. David Darom (The Hebrew University of Jerusalem, Israel) for taking the photographs of the specimens of Pleurosicya mossambica.

\section{REFERENCES}

Eschmeyer W.N. (ed.) 2014. Catalog of fishes (electronic version) [updated 4 December 2014].

Goren M. 1984. Three new species and two new records for the Red Sea of invertebrate associated gobies (Gobiidae, Pisces). Cybium 8 (1): 71-82.

Golani D., Bogorodsky S.V. 2010. The fishes of the Red Sea-reappraisal and updated checklist. Zootaxa 2463: 1-135.
Goren M., Dor M. 1994. An updated checklist of the fishes of the Red Sea. CLOFRES II. The Israel Academy of Sciences and Humanities, Jerusalem.

Hubbs C.L., Lagler K.F. 1947. Fishes of the Great Lakes region. Bulletin, Cranbrook Institute of Science (Bloomfield Hills, Michigan) 26: 1-186.

Larson H.K. 1990. A revision of the commensal gobiid genera Pleurosicya and Luposicya (Gobiidae), with descriptions of eight new species of Pleurosicya and discussion of related genera. The Beagle, Records of the Northern Territory Museum of Arts and Sciences 7 (1): 1-53.

Received: 6 January 2015

Accepted: 19 February 2014

Published electronically: 30 June 2015 